\title{
SUPPLY CHAIN MANAGEMENT MODEL ON START-UP BUSINESS
}

\author{
Romauli Nainggolan \\ Lecturer, Universitas Ciputra Surabaya, Surabaya, Indonesia
}

\begin{abstract}
Supply chain management is an important part in achieving the efficiency of the company. The supply chain for early-stage businesses is further compared to large and advanced businesses. This research offers a management model for the supply chain of non-F \& B start-up businesses established by Universitas Ciputra students and discuss the strategy for planning raw materials from suppliers. The consideration of choosing the non-Food \& Beverage businesses was merely because the products have longer physical endurance so they can be stored in warehouses for preparation, so it is assumed to have longer supply chain. The research respondents were 30 non-Food and Beverage start-up businesses operating more than two years. From the results of the study there were two findings. First, there are three kinds of supply chain management models adopted by the student's start-up business. Model 1 consist of Suppliers - Manufacturers - Distributors - Resellers - Consumers. Model 2 consist of Suppliers - Manufacturers - Resellers - Consumers. Model 3 consist of Suppliers - Retailers - Consumers. Second, in order to provide raw materials, $40 \%$ non-F \& B student's start-up businesses using a small supplier strategy with two suppliers. 7\% start businesses using many supplier strategies with four suppliers. Non-Food \& Beverage businesses have longer physical endurance so they can be stored in warehouses for inventory
\end{abstract}

Keywords: supply chain management, start-up business, strategy

\section{INTRODUCTION}

Decisions of companies managing the supply chain well will have an impact on the effectiveness and efficiency of the company. Supply chain managers play an important role in achieving this (Alfian, 2014). Lack of understanding of supply chain management often raises problems such as increased transportation costs, inventory costs and resource costs. In addition, the lack of understanding of the importance of supply chain management in the company made the response of very long time the production of goods to consumers. The main problem in the supply chain is related to: (1) determining the right level of outsourcing, (2) managing the purchase or procurement of goods, (3) manag-

"Corresponding Author.

e-mail: romauli.nainggolan@ciputra.ac.id

https://doi.org/10.37715/jee.v8i2.1122 ing suppliers, (4) managing relationships with customers, (5) identifying problems and responding to problems quickly managing risks (Chopra et al., 2007).

To overcome this problem, business owners must know the supply chain and manage it appropriately (Anwar, 1990). Because the longer the supply chain will cost more. Start-up business owners need to regulate the supply chain in each company. In Yogyakarta SMEs use a small supplier strategy and take raw materials directly to the nearest supplier aimed at reducing transportation costs (Fajarwati, 2015). Therefore, the SCM concept is operationally focused on efforts to minimize physical costs that will match the efficiency strategy and carry out many physical activities, such as finding raw 
Romauli Nainggolan / Supply Chain Management Model on Start-up Business /

JEE, Vol. 7, No. 2, September 2019, pp 65-72

materials (sourcing), production, material storage, distribution, product returns.

Early-stage business owners need to know five actors in the supply chain, namely suppliers, manufacturers, distributors, retailers and consumers. Where there are two streams that occur in the supply chain, namely the flow of goods/services and the flow of money. Even though the links in the start-up business are mostly still short, collaboration between suppliers and companies, distributors, retailers, and customers enables the novice business to efficiently manage the flow of materials, products and information. Not a few business owners of non-F \& B start-ups experience problems in managing the purchase or procurement of goods and managing suppliers. Therefore, this study aims to identify supply chain management models at non-F \& B business start-ups owned by Ciputra University students that have been implemented so far. And it aims to investigate supply chain management strategies for raw material inventories from non-F \& B suppliers. So that this research contributes to academics making supply chain modelling modules. And contribute to business people to achieve company efficiency with a strategy to supply raw materials.

\section{METHOD}

This research is a descriptive qualitative research by observing the business supply chain activities of non F\&B student's start-up business in Universitas Ciputra. Observing business activities from upstream to downstream to 30 UC start-up businesses is not done in factories or in production houses, but in the craftsmen' workshop. Every year 200 business groups start up at Universitas Ciputra. Not a few businesses have stopped on the road due to internal failures. From some businesses that still survive, researchers will observe the supply chain management model with the following stages of research:

- Compilation of design research and questionnaires.

- Identify start-up businesses that operate over two years and sell non F\&B products.

- Communication and scheduling between researchers and respondents.

- Collection of field data through questionnaire filling and interviews.

- Data processing starts with tabulation of data and information.

- Obtain data by identifying the supply chain model

- Finished by processing data and information

The object of this research is Universitas Ciputra's non F\&B start-up business which has been operating for more than two years. Business owners are used as respondents because they are considered representative and know the state of their business, especially regarding the supply chain from suppliers to consumers. The number of objects of observation is 30 start-up non F\&B businesses. Research methods are used to examine the condition of natural objects where the researcher is a key instrument or subject. The criteria for choosing informants as resource persons in this study are UC students as startup business owners, especially goods production companies and have been established for more than two years.

This research is limited to start-up business with criteria: (1) it has been established for more than two years, (2) companies that produce goods. This is because the flow of goods and financial information is easier to 
track so that it is easy to find out the problems that arise in the supply chain, (3) Having permanent production, operational, sales and marketing activities, and (4) Having a clear market segment.

The main instrument of data collection in qualitative research is the researcher itself or what is called the human instrument (Bungin, 2001). Qualitative objectives are describing a situation or phenomenon that is occurring, therefore an instrument is needed because researchers are required to be able to find data raised from certain phenomena or events, researchers in carrying out interviews even though they are unstructured but at least the researchers use the question questions to be noted as notes. which is called the interview guide.

Supply chain management is a series of relationships between companies or activities that carry out the distribution of supply of goods or services from the place of origin to the place of buyers or customers. The supply chain concerns on-going relationships regarding goods, money and information. Goods generally flow upstream to downstream, money flows from downstream to upstream, while information flows both from upstream to downstream and downstream to upstream. Viewed horizontally, there are five main components or actors in the supply chain, namely suppliers (suppliers), manufacturers (goods manufacturers), distributors (wholesalers), retailers (retailers), customers (customers).

Vertically, there are five main components of the supply chain, namely buyers (buyers), transporter (transporters), warehouses (stores), sellers (sellers), and so on (See Figure 1).

Descriptive analysis was conducted to observe the phenomenon of the application of supply chain management business start-up UC students. Data Analysis Techniques This research is a descriptive explorative approach in analysing existing problems. The use of an exploratory descriptive approach is used because of the nature of research that wants to reveal the problem phenomena to develop a supply chain management model for UC students' startup businesses that are expected so that they are in accordance with the results to be achieved. This study also uses an interactive analysis model. The interactive data analysis technique (Miles \& Huberman in Herdiansyah, 1994) consists of four steps that must be done. The first stage is the data collection stage, the sec-

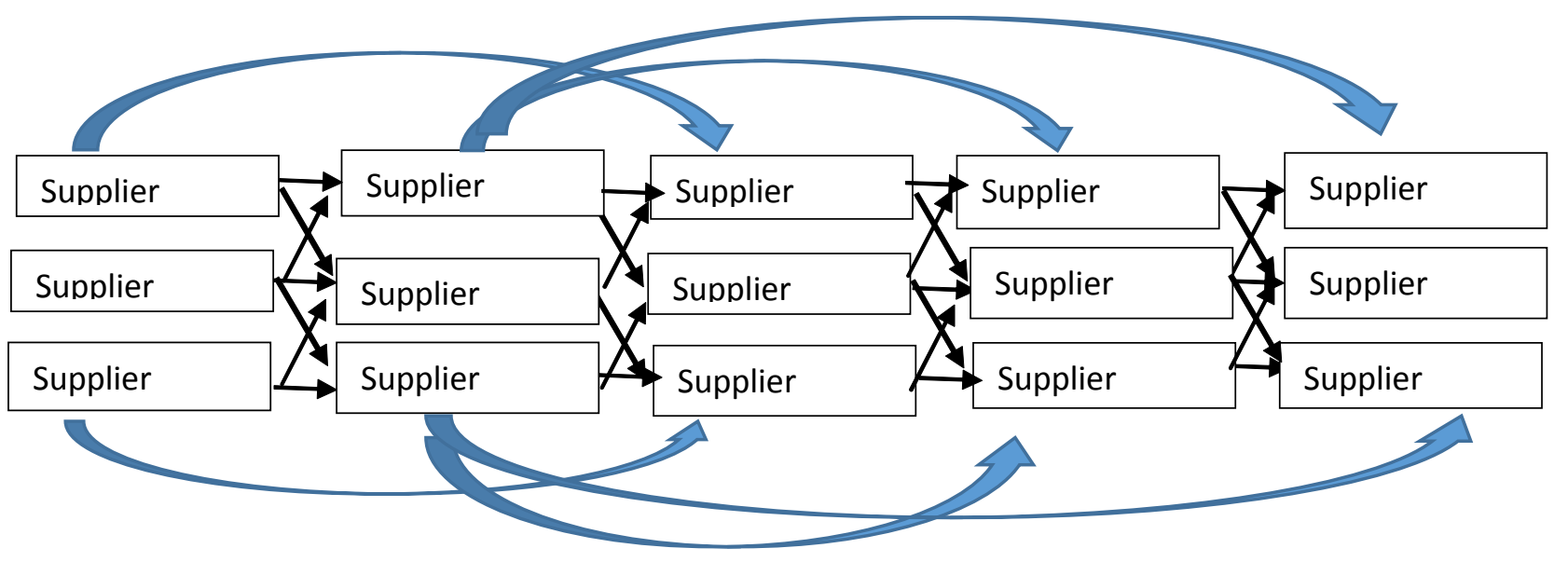

Figure 1 Flow of the Supply Chain 
Romauli Nainggolan / Supply Chain Management Model on Start-up Business /

JEE, Vol. 7, No. 2, September 2019, pp 65-72

ond stage is the data reduction stage, the third stage is the data display stage, and the fourth stage is the stage of drawing conclusions and/or the verification stage.

These stages will be explained as follows:

- Data collection.

The process of collecting data in this study was carried out by interviewing and documentation to the start-up students of Universitas Ciputra business owners. Interviews were conducted at the campus and outside the campus by determining the suitability of meeting time.

- Data reduction with coding and categories. The essence of data reduction is the process of combining and uniforming all forms of data obtained into one form of writing (script) to be analysed. The way that can be taken is to read all the transcripts then coded, which are summarizing, highlighting, messaging, capturing the essence of the interview results which are then grouped into categories.

Table 1 Type of Business and Number of Suppliers in the Start-up Business

\begin{tabular}{cllc}
\hline No. & \multicolumn{1}{c}{ Name of Business } & \multicolumn{1}{c}{ Line of Work } & $\begin{array}{c}\text { Supplier } \\
\text { Amount }\end{array}$ \\
\hline 1 & Remile & Leather goods & 2 \\
2 & Tukangku & Construction service & 3 \\
3 & East Side Culture & Weaved fabrics goods & 2 \\
4 & Catalyst & Clothing & 2 \\
5 & Raksha & Clothing & 2 \\
6 & Papilion & Florist & 5 \\
7 & Partners Learning Center & Learning Centre & 2 \\
8 & Remix & Accessories, casual wear, street & 20 \\
& & wear & \\
9 & Lekure & Leather goods & 3 \\
10 & Kriyakarti & House decoration & 3 \\
11 & Bluff Footwear & Shoes reseller & 3 \\
12 & Berlian Garmen & Garment & 4 \\
13 & Tangkong & Fashion product online shop & 5 \\
14 & Clement & Leather goods & 5 \\
15 & Custton motor shop & Motor bike accessories: shirt, & 6 \\
& & helmet & 2 \\
16 & Monokuro Tee & T-shirt & 2 \\
17 & Rollette & Leather goods & 5 \\
18 & Taniago & Ladies clothing & 3 \\
19 & Geometric & Second-hand furniture & 2 \\
20 & Seribu Satoe & Wood watches & 6 \\
21 & De Bali & Accessories and stationary & 3 \\
22 & Reich & Leather goods & 3 \\
23 & Dakara & Leather footwear & 2 \\
24 & BOCA & Booth & 2 \\
25 & Hi Makeups & Make up & 2 \\
26 & 64 Visual & Digital marketing and consepting & \\
27 & Towing & Tow-truck & Ladies clothing \\
28 & Mely & Rattan Bags & 2 \\
29 & Rubashaka & & 2 \\
\hline
\end{tabular}

Source: Internal Data, 2019 
Categories are selected based on the results of coding that have similar themes. In this study coding will be done for the number of distribution channels of supply chain actors, for example suppliers - consumers -.

- Display data.

Display data is processing semi-finished data that has been uniform in written form and already has a clear theme flow. Display data is presented in narrative form in accordance with the research objectives. This research display is in the form of a supply chain model with various numbers of actors involved in the supply chain. Likewise, the display of this research will show the strategy of supply chain management in terms of inventory from various suppliers.

- Conclusion or Verification.

Conclusions or verification is the last step in the qualitative data analysis series according to this model. The conclusion in this series of qualitative data analysis is to conclude the results of the study by comparing the researchers' questions with the results of the research.

\section{RESULTS AND DISCUSSION}

The study was conducted on 30 start-up businesses owned by UC students specifically non F\&B businesses. Respondents interviewed were business owners so they mastered the production process to the consumers. From the results of interviews with 30 start-up businesses owned by Universitas Ciputra students, various combinations of suppliers were obtained by each company. Table 1 below describes the business name and type of business start-up and the number of suppliers used to provide raw materials.
From the results above, all start-up businesses have supplier sources ranging from 2-5 suppliers. Suppliers that provide raw materials from various cities, various shops in Surabaya. This shows that start-up business owners get raw materials not from initial (first) suppliers, but start-up business owners get raw materials from large distributors, such as stores. This means that there is a long supply chain that is happening in the market. But in this study, the supply chain is limited only to suppliers or product providers for start-up businesses. The percentage of suppliers of start-up businesses can be seen in Table 2 below.

Table 2 Number of Business Start-up Suppliers

\begin{tabular}{ccc}
\hline Supplier's Amount & Amount & Percentage \\
\hline 2 & 12 & $40 \%$ \\
3 & 8 & $26.7 \%$ \\
4 & 2 & $6.7 \%$ \\
5 & 8 & $26.6 \%$ \\
Total & 30 & $100 \%$ \\
\hline
\end{tabular}

Source: Internal Data, 2019

Most start-up business owners use 2 suppliers reaching $40 \%$. Whereas at least using 4 suppliers is only $6.7 \%$. After purchasing raw materials from suppliers, then the activities carried out are conducting the production process (manufacturing or factory) from raw materials to finished products. Then followed by marketing activities by distributing or distributing goods to consumers. Product marketing is carried out by business owners starting up through various distribution channels which can be seen in Table 3.

In Table 3 above, the economic actors underlined are non F\&B start-up business owners. The percentage is $46.7 \%$. Start-up businesses use 4 distribution chains where business owners start up as retailers and then market 
Romauli Nainggolan / Supply Chain Management Model on Start-up Business /

JEE, Vol. 7, No. 2, September 2019, pp 65-72

Table 3 Distribution Channels Used by Business Start Up

\begin{tabular}{lcc}
\hline \multicolumn{1}{c}{ Distribution Channel } & Amount & Percentage \\
\hline Suppliers - Manufacturers - Retailers - Consumers & 14 & 46.7 \\
Suppliers - Manufacturers - Distributor - Retailers - Consumers & 2 & 43.3 \\
Suppliers - Manufacturers - Consumers & 6 & 20 \\
Suppliers - Retailers - Consumers & 8 & 26.6 \\
Total & 30 & $100 \%$ \\
\hline
\end{tabular}

Source: Internal Data, 2019

directly to consumers. The lowest presentation of the distribution chain is $6.7 \%$ where the business owner is the seller from the craftsman to the retailer. Based on the results of identification, there are 3 (three) supply chain manage-

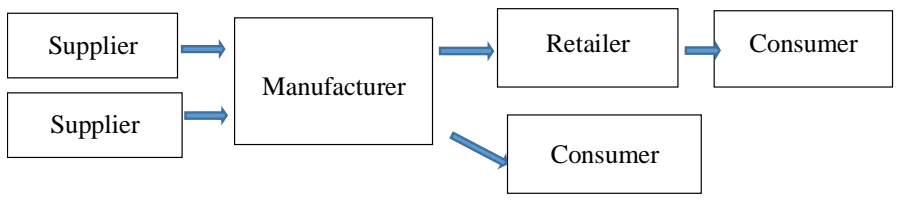

Figure 4 SCM Model 2

Model 3

Suppliers - Distributors - Retailers - Consumers The third supply chain management model is that business owners start up as distributors from various suppliers, then sell to retailers and consumers. variations of 2-5 suppliers then makes the manufacturing process by making products and directly selling them to consumers.

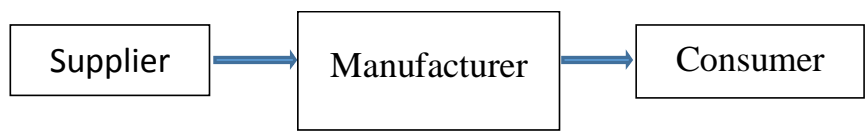

Figure 3 SCM Model 1

\section{Model 2}

Supplier - Manufacturer - Retailer - Consumer The second supply chain management model is that the start-up business uses 2-5 suppliers and then does the manufacturing process by making products and selling them to retailers, finally reaching consumers.

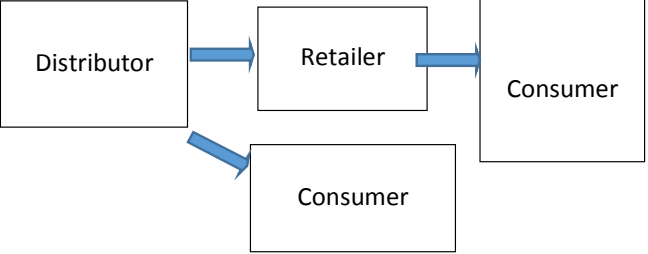

Based on the analysis as in Table 2, we can identify the supply chain management strategies used by the start-up business in determining suppliers, namely:

- Business start-up uses a slightly supplier strategy with 2 suppliers, $40 \%$.

- Business start-up uses a little supplier strategy with 3 suppliers, namely $26.7 \%$.
Figure 5 SCM Model 3 
- Business start-up uses a slightly supplier strategy with 4 suppliers, 6,7\%.

- Business start-up uses a strategy of many suppliers with 5 suppliers, namely $26.6 \%$.

Various supply chain management issues that have been implemented by non-F \& B start-up businesses. The characteristics of a start-up business in general are:

- In providing raw materials, start-up business owners buy several stores in the city and outside the city. The selection of suppliers is associated with the cheapest price.

- The start-up business owner should have a network to the original supplier because purchasing raw materials from shop suppliers and supermarkets is more expensive than purchasing raw materials from the original supplier.

- Knowledge of product marketing and technological knowledge must be owned by F \& B start-up business owners because it relates to the distribution of their products to consumers.

\section{CONCLUSION}

The Supply Chain Management Model That Has Been Implemented By Universitas Ciputra's Business Start-Up Namely: (1) Model 1: Supplier - Reseller - Consumer, (2) Model 2: Supplier - Manufacturing - Retailers - Consumers, (3) Model 3: Supplier - Manufacturing - Distributor - Retailer - Consumer.

The supply chain management strategy used by start-up business owners in determining suppliers is: (1) Business start-up uses a slightly supplier strategy with 2 suppliers, 40\%, (2) Business start-up uses a little supplier strategy with 3 suppliers, namely 26,7\%. (3) The start- up business uses a strategy of quite a lot of suppliers with 4 suppliers, 6.7\%. (4) Business start-up uses a strategy of many suppliers with 5 suppliers, namely $26.6 \%$.

\section{REFERENCES}

Alfian, C. S. (2014). Pengembangan Model Manajemen Rantai Pasok Energi di Indonesia. Bandung.

Anwar, S. N. (1990). Manajemen Rantai Pasok/: Konsep dan hakikat, 92-98.

Chopra, S., Me, G. E., \& Meindl, P. (2007). Supply Chain Management, 265-275.

Fajarwati. (2015). Model Manajemen Rantai pasokan pada usaha kecil dan menengah di Yogyakarta. Ekp Vol.13 No.4. Yogyakarta. Retrieved from http://repository.umy.ac.id. Heizer, Jay \& Barry. R, 2008. (2010). Prinsip prinsip Manajemen Operasi. PT Salemba Jakarta.

Romauli Nainggolan. (2017). Model MRP UMKM Surabaya. Medan: USU Press. Retrieved from https://dspace.uc.ac.id/handle/ $123456789 / 1246$

Shapiro. (2006). Modelling The Supply Chain, $2^{\text {nd }}$ Edition, Suxbury Press, Pacific Grove, California, 59-72.

Talumewo, P. O. E., Kawet, L., \& Pondaag, J. J. (2014). Analisis Rantai Pasok Ketersediaan Bahan Baku Di Industri Jasa Makanan Cepat Saji Pada KFC Multimart Ranotana. Jurnal EMBA, 2(3), 1584-1591.

Bungin, B. (2014). Penelitian Kualitatif: Komunikasi, Ekonomi, Kebijakan Publik, dan Ilmu Social Lainnya. Edisi kedua. Cetakan ke 7. Jakarta: Prenada Media Group.

David Mc Clure, (2012). Start up metric, Linkedln Learning, 2. 
Romauli Nainggolan / Supply Chain Management Model on Start-up Business /

JEE, Vol. 7, No. 2, September 2019, pp 65-72

Fitzsimmons, James A. dan Mona J. Fitzsimmons, (2006). Service Manajemen. International Edition. Edisi 5. NewYork: The McGrawHill.

Indrajit, Richardus Eko dan Djokopranoto, (2003). Konsep Manajemen Supply Chain:
Strategi Mengelola anajemen Rantai Pasokan Bagi Perusahaan Modern diIndonesia, PT Gramedia Widiasarana.

Miles, M.B \& Huberman, A.M. (1994). Qualitative data analysis: An expanded sourcebook $\left(2^{\text {nd }} e d\right)$. Thousand Oaks, CA: SAGE. 